\title{
LETTERS
}

\section{Tighter gun control laws are unlikely to prevent shootings}

Dr. Stanbrook's editorial comes across as a bit of a petulant rant and in that respect is as bad as the actions of the "Canadian gun lobby." 1 The editorial is full of manipulative and questionable analogies, but is short on facts. I am sure Dr. Stanbrook is aware that the weapon involved in the Danforth shooting was a handgun originating in the United States and, of course, completely illegal in Canada under existing law. Stricter gun control would have made absolutely no difference to that event, so it strikes me as emotional manipulation to include it in the argument.

If there is a public health crisis here, it is inadequate resources for mental health treatment in Canada. This applies to the perpetrators of these horrendous but rare acts such as the Danforth shooting, and also applies to the many who choose to end their lives with a gun because of mental illness.

Would tougher gun control laws prevent shootings and suicides? I doubt it. What they would do is punish the 2 million legal gun owners in Canada who would never dream of harming another person.

Dr. Stanbrook suggests that physicians are well equipped to analyze information and come to sensible conclusions. If that is correct, the first thing we need to do before drawing any conclusions about the adequacy of gun control is to be familiar with the current law. I invite anyone with an interest to read the Firearms Act. Of course, the interpretation and enforcement of the act varies a bit in different provinces, and there are frequent amendments and proposed amendments. After that, you can form a reasoned opinion.
The editorial references the atrocity that took place in New Zealand. I am troubled that the root cause of these events, which is the hatred, intolerance, ignorance and bigotry that exist in this world, has somehow been lost in the fervour over gun control.

\section{Martin N. Scanlon PhD MD}

Physician, University of Calgary, Calgary, Alta.

Cite as: CMAJ 2019 August 26;191:E947. doi: $10.1503 / \mathrm{cmaj} .72613$

\section{Reference}

1. Stanbrook MB. Gun control: a health issue for which physicians rightfully advocate [editorial]. CMAJ 2019;191:E434-5.

Competing interests: Martin Scanlon is a gun owner, hunter and member of a target shooting club. 